\title{
Power Approaches to Policy-Making
}

\author{
Tej Raj Pokharel \\ Lecturer \\ Nepal Commerce Campus, Faculty of Management, T.U.
}

\begin{abstract}
Society is the mixture of mass and elite group. Elite group of society remains in apex and forcefully take the space in decision making process, direct and instruct the mass as well as administrators and drag the power in their own hands. Elites manipulate mass opinion and sentiments. They rule masses of people. Elite theories introduce not only elites, but also new important subjects like power, and raise questions for example on oligarchical tendencies in democracy
\end{abstract}

Keywords: elite, mass, administration, democracy, manipulation.

\section{Background}

A policy is a purposive course of action taken or adopted by those in power in pursuit of certain goals or objectives (Sapru, 2012). For decision or policy making by individual and group, no single frame work can possibly explain everything (Mill, 1963). Contribution to decision or policy analysis invariably overlaps and interact. One focus serves as critique of another. Policy is a plan of action, usually based on certain principles and decided on by a body or individual, designed to administer, manage and control access to resources. In discussions on evidence-informed policy processes, policy typically refers to the explicit (and sometimes implicit) plan of action prepared by international, regional, national or sub-national inter-governmental or governmental bodies. In other words the focus is on public rules and regulations. While NGOs or private sector organizations also have policies, these are excluded from our discussion because they are not public in nature.

One of the way to study the policy making is through the power approach. The power approach view policy making as something which is influenced and determined by the structure of power: class interest group bureaucratic and political arrangement etc. In this article, discussion will be confined to:

- Elite theory

- Group and group think theory

\section{Elite theory of the policy process}

The theory posits that a small minority, consisting of members of the economic elite and policyplanning networks, holds the most power-and this power is independent of democratic elections .Elite theory of policy process based on the proposition that power is concentrated in the hand of few elites .Policy making, according to elite theory, is a process which works to the advantages of these elites. The theory holds that in the real world there are those at the top with power and the mass (at the down) without power. The theory also contends that the elite, whose members share common value and have more money, education and power, governs the masses who are apathetic and ill-informed about public policy. In an environment which is characterized by apathy and information distortion, elites informs mass opinion on policy issues more than mass influence elite opinion. Top down Policy making, argues that U.S. public policy does not result from the "demands of the people", but rather from elite consensus found in Washington, D.C.-based non-profit foundations, think tanks, special-interest groups, and prominent lobbying and law firms. (Dye, 2004) 


\section{Objectives of the Study}

\section{General objectives}

The general objectives of this study are as follows:

- $\quad$ To provide the insight knowledge of elite group who play the major role in policy making.

- $\quad$ To provide the knowledge about the masses whose numbers are more but are apathetic and ill-informed about the public policy.

- To recognize the movement of elite-mass conflict.

\section{Specific Objectives}

The Specific objectives of this study are as follows:

- To identify the relationship between elite and mass their formation, role, organization and influence in society.

- To convey the message that elite are somehow incompatible with democracy.

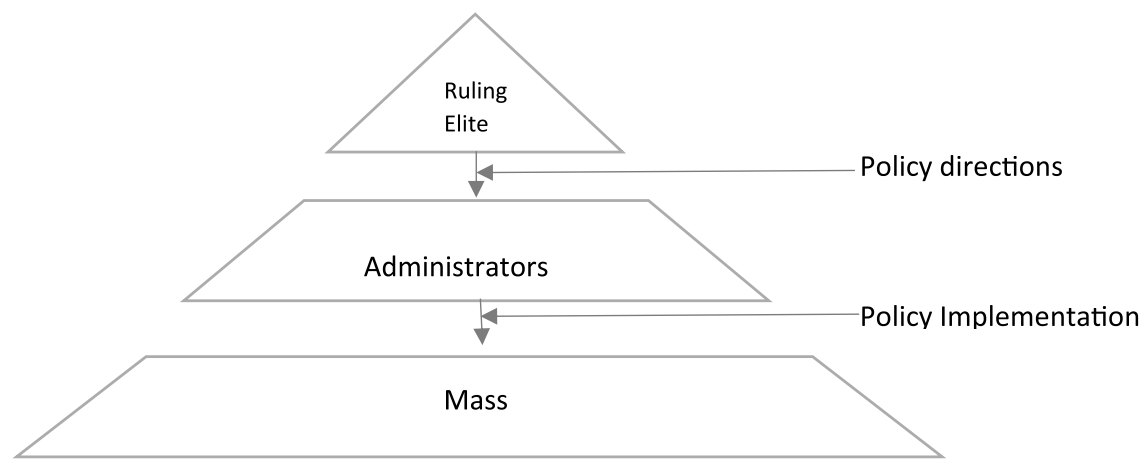

Elite theory of policy process

Source: Adapted from Thomas Dye (2004)

In this framework policy flows down-ward from the elite to the mass. Public policy is viewed as the preferences and values of governing elite (Dye and Zeigler, 2004). This theory has its origin in the work of Mosca and Pareto. They argued that, contrary to Marx, elitism is inevitable and the classless society is a myth. This theory assume that those who are at the top holds more power. Later Mosca modified his view and argued that the democracy could be viewed as a form of politics in which elites competes for the people's vote in order to secure legitimacy for the elite rule. Drawing upon the Mosca's ideas, Robert Michel's in a study of political parties argued that there was an iron law of oligarchy which operated in organization.

\section{Methods of the Study}

This article follows exploratory as well as qualitative research design to analyze the concept of elite and mass and their movement. A design of present study is based on secondary data by gathering information from previous research articles, books, magazines, newspaper, journals, the internet and media where applicable

\section{Propositions of the Elitism}

Elitism is the belief that a society or system should be led by an elite and society is divided into the elites who govern and have the power to decide on public policy, and the masses who are governed and do not have power to decide on public policy. Elites share common values and have money education and power than the masses who are apathetic and ill- informed. Elite members are drawn disproportionately from the higher socio economic strata of the society. Public policy does not reflect the demands of masses, 
Vol. 4, No. 1

but rather the preferences and value of governing elite shape mass opinion on policy issue more than masses shape elite opinion (Dye, 2004).

In political science and sociology, elite theory is a theory of the state that seeks to describe and explain power relationships in contemporary society. The theory posits that a small minority, consisting of members of the economic elite and policy-planning networks, holds the most power-and this power is independent of democratic elections. Through positions in corporations or on corporate boards, and influence over policy-planning networks through financial support of foundations or positions with think tanks or policydiscussion groups, members of the "elite" exert significant power over corporate and government decisions. An example of this belief is in the Forbes magazine article (published in December 2009entitled- The World's Most Powerful People, in which Forbes purported to list the 67 most powerful people in the world, assigning one "slot" for each 100,000,000 of human population. The basic characteristics of this theory are that power is concentrated, the elites are unified, the non-elites are diverged and powerless, elite's interests are unified due to common backgrounds and positions and the defining characteristic of power is institutional position.

Elite theory opposes pluralism, a tradition that assumes that all individuals, or at least the multitude of social groups, have equal power and balance each other out in contributing to democratic political outcomes representing the emergent, aggregate will of society.(Dye,2004)

It is the psychological traits or characteristics of elites which separates them from the masses (Pareto, 2014). He classified elites into two types - those with the power or traits of 'lions' who use force to gain or retain power like military dictators and those who had the traits of a 'fox' using cunning and guile to get their own way. While this classical elite theory is often criticized for its simplicity.

Elite theory stands in opposition to pluralism in suggesting that democracy is a utopian ideal. It also challenges any theories which argue the state acts as an autonomous institution.

Elite theory's origins lie most clearly in the writings of Gaetano Mosca (1858-1941), Vilfredo Pareto (1848-1923), and Robert Michels (1876-1936). Mosca emphasized the ways in which tiny minorities outorganize and outwit large majorities, adding that "political classes" - Mosca's term for political elites usually have "a certain material, intellectual, or even moral superiority" over those they govern (1923/1939, 51). Pareto postulated that in a society with truly unrestricted social mobility, elites would consist of the most talented and deserving individuals; but in actual societies elites are those most adept at using the two modes of political rule, force and persuasion, and who usually enjoy important advantages such as inherited wealth and family connections. Pareto sketched alternating types of governing elites, which he likened, following Machiavelli, to lions and foxes. Michels rooted elites ("oligarchies") in the need of large organizations for leaders and experts in order to operate efficiently; as these individuals gain control of funds, information flows, promotions, and other aspects of organizational functioning. Power becomes concentrated in their hands ( Higley ,2010).

Elite group consists of not only of prestigious and "established" leaders - top politicians, important businessmen, high-level civil servants, senior military officers - but also, in varying degrees in different societies, relatively transitory and less individually known leaders of mass organizations such as trade unions, important voluntary associations, and politically consequential mass movements. "Counter-elites" are subsumed by this definition because they clearly have the organized capacity, although perhaps mainly through negation, to affect political outcomes regularly and substantially. It is important to stress that this is a limited and specifically political definition of elites. It is restricted to persons who are at the top of the pyramid or pyramids of political, economic, and social power (Putnam, 1976). It does not consider all those in a society who enjoy high occupational, educational, or cultural statuses to be elites in a political sense. Meaningfully democratic institutions and practices depend upon the type of elite that a society has. No type of elite is compatible with the full democratic ideal, and only one of the three types is reasonably compatible with the stable democratic politics that are practiced in Western countries and a few others today. 


\section{Schumpeter's contribution to Elitism}

If the views and argument of Mosca, Pareto and weber were accepted, then democracy explained in terms of government by the people, will be unreal and idealistic the problem reconciling of the elitism with the democratic legitimacy has been resolved by the economist Joseph Schumpeter.

Schumpeter applied an economic approach to the problem of democratic legitimacy. He argued that elitism would be legitimated in a democracy by a political market composed of political parties and rival elites .The people were involved in appropriate decision making process. This model of Schumpeter was taken to its logical conclusion in Down's economic theory of democracy. (Downs, 1957).

\section{Lasswell's and Mills' Contribution to Elitism}

"The study of politics is the study of influence and the influential.....The influential are those who get the most of what there is to get ....Those who get the most are elite, the rest are mass " ( Lasswell, 1936 )

Different skill groups had emerged from class struggle in the democracy. (Laswell, 1936). These skill group included those skill in the use of violence such as military and police elite.

However, none of the three elite types is reliably conducive to even this limited form of democracy. The most common political situation that of disunited elites, has the basic feature of institutional instability. The circumstances in which disunited elites become ideologically or consensually united are unlikely to appeal to people with democratic sentiments. An ideologically united elite does not allow competitive politics, and where it exists meaningful actions motivated by democratic sentiments are nearly impossible. The basic settlements in which a few consensually united elites originated historically had as their principal features substantial elite autonomy from mass pressures together with the sacrifice of deeply held political principles for which opposing elites and their supporters had long stood. Position of their rapidly changing workforces than in the inability of these work forces to provide employment for large parts of swollen and mostly young non-elite populations. The illustrative point, in any case, is that non-elite configurations, sketched here as distinct workforce compositions and concomitant mixes of orientations toward elites, rule out certain elite actions and political outcomes at different stages in socioeconomic development, but they do not determine what elites will do and what political outcomes they will produce. Thus, early in socioeconomic development non-elites tend toward a hostile view of power exercises by elites, and their impoverished situations give non-elites little reason to fear a general leveling of existing hierarchies. If elites are exceptionally incompetent or unlucky, a collapse of government authority that triggers a leveling revolution is possible. But elites may circumvent this by couching effective appeals for non-elite support in terms of religious and other traditional beliefs.

In socioeconomic development's industrial stage, a shift to fascist rule is possible, although entrenched elites may circumvent it by holding elections in which leveling forces simply lack sufficient numbers to prevail. What is not possible in industrial societies - in other words, what is precluded by the non-elite configuration - is a successful leveling revolution, and, pace Marx, none has occurred. Meanwhile, industrial societies appear to prevent sudden and deliberate settlements of basic elite disputes because their relative complexity makes the elite stratum large and not sufficiently autonomous from non-elites. Elite actors are numerous and may give their primary allegiance to the partisan interests of the mass organizations and movements they head. Negotiating behind the political stage to compromise principled interest positions that elite factions have repeatedly taken when mobilizing non-elite support and then getting followers to accept such compromises is unlikely. Forming a winning political coalition that successfully defends existing hierarchies. It is the more plausible option for elites in industrial societies, similarly, elites and non-Elites in Postindustrial Conditions. How do elites and non-elites affect each other in postindustrial conditions? Consequently, elites needed less recourse to ideologies for the reconcile purpose of their conflict, such as socialism and liberalism that is essential for them in order to justify their statuses, policy positions, and governing actions. Elite political discourse shifted to discussing affluence and the welfare state as solvents of historic discontents and problems. With high productivity and nearly full employment, the absence of 
Vol. 4, No. 1

serious economic downturns, a shrunken working class acquiring middle-class life styles, and no other large and obviously discontented collectivities in sight, there was the appearance of considerable harmony among non-elite populations. Elites, accordingly, adopted a more and more rude managerial posture and they voiced a complacent belief that merely "fair" treatment of individuals and groups would ensure social progress and tranquility (Thoenes, 1966).

With the passage of time, however, the greater non-elite harmony and elite complacency that appeared to be the principal political effects of postindustrial conditions diminished. Increased crime, narcotics use, and other deteriorating social conditions became apparent in many cities; a seemingly intractable form of poverty spread in urban slums and rural backwaters; and many young people with essentially privileged family backgrounds displayed considerable alienation and discontent. These trends suggested that postindustrial conditions could be more difficult politically than they first seemed. Postindustrial conditions are in important respects the terminus of socioeconomic development. They complete the conversion of workforces that consisted overwhelmingly of peasants and artisans at development's outset into workforces pervaded by bureaucratic and service personnel.

It is quite unlikely that some further stage of development, conceived in terms of new basic kinds of work and new workforce components, lies beyond postindustrial conditions. If this is so, it must be asked whether postindustrial societies can over the longer haul remain viable politically without the sense of progress and spread of hope that development engendered historically. Can postindustrial societies "stagnate" indefinitely in their non-elite configuration without suffering major political disruption? One concern is the increased empathy between elites and non-elites that occurs in postindustrial conditions. The preponderance of bureaucratic and service work intermingles or balances the previously distinct social strata. Persons more frequently and routinely ascend to elite positions from non-elite origins and locations than happens in more rigidly stratified societies at earlier development levels. As a consequence, not a few persons holding elite positions in postindustrial conditions see themselves as one of a kind with non-elites, among whom they frequently have intimate personal associates and for whom they have considerable empathy. These close and empathetic ties to non-elites help ensure that elite persons are better able to determine measures that at least partially assuage non-elite discontents and aspirations. But what may happen if it is not possible to assuage non-elites? Presumably, actions and measures ranging from deception to discouragement to outright repression will be more reviled by non-elites and harder for elites to take. A still wider difficulty confronts elites in postindustrial conditions. In all earlier stages of socioeconomic development political action was not generally required to keep most persons steadily engaged in the performance of necessary work. For the most part, internalized attitudes and customary social controls supplied by neighbors and work mates sufficed. In postindustrial conditions, however, such close social controls, along with most religious and other traditional belief systems are made greatly weaker or less effective. In earlier stages of socioeconomic development, moreover, most persons worked diligently in order to stave off dreadful personal circumstances - dismissal, eviction, hunger, etc. - and a significant proportion worked without surcease because they could plausibly believe that by doing so their strong personal ambitions could be realized. In these earlier societies only a small number of specially favored persons - mainly the offspring or friends of the rich and powerful - were unmotivated to work in disciplined ways and were inclined toward a self-indulgent, if perhaps esthetically satisfying, leisure. It is easy to see that the proportion of people who are unmotivated for steady work increases markedly in materially affluent and empathetically indulgent postindustrial conditions. It is useless to ignore this by holding that modern technology greatly reduces the need for human labor. Responsible work is not readily parceled out in little pieces in any society. Some tasks must still - and presumably must always - be performed with care, diligence, and forethought, and those who perform them will not allow a large body of essentially idle people, however decorative they may be, to receive substantial rewards for their idleness. This disjunction between the diligent and the idle signals a growing clash between segments of non-elite populations in postindustrial societies, although it is uncertain if this clash will have a magnitude that consensually united 
elites are unable to manage. Elite Theory's Limits Elite theory's predictive pretensions are necessarily modest. Elite behavior cannot be inferred, let alone projected, from knowledge of non-elite configurations and propensities. For instance, neither the creation nor persistence of a consensually or an ideologically united elite is discernibly linked with non-elite propensities. The probability of a united elite of either kind forming and creating stable political institutions can only be guessed at from knowledge of recent elite history. Does this history display long and costly, but essentially inconclusive, warfare between disunited elite factions who, in consequence, may be disposed toward a basic settlement of their disputes? Have elites recently suffered a defeat so grave that the way may be open for a well-organized but previously peripheral group to seize and consolidate power in revolutionary circumstances? The difficulty is not merely that elite behavior is poorly understood; it always contains enough elements of arbitrariness, capriciousness, or simple lack of obvious explanation to defy deterministic explanation. Thus, while societies have displayed similar non-elite configurations during socioeconomic development, no such regularities in the behaviors and configurations of their elites can be identified. Any theory that recognizes this disjunction between elites and non-elites must allow considerable leeway for political accident and unpredictable political choice, so that it's explicative claims must be quite modest. It must also be recognized that elite theory is distasteful to many because it rules out the more ideal aims and outcomes that are regularly voiced by intellectuals, mass movement leaders, and even loosely predicted by social scientists. Elite theory has no place for idealized visions of democracy or social revolution, nor does it have a place for the spread of new values that dispose human beings toward a consistent and thorough altruism. Human conflicts inevitably dilute social cohesion and constitute political problems that elites must manage as best they can. However well or poorly they accomplish this task, elites are the central actors in politics, but the theory that centers on them is unlikely to have many enthusiastic adherents.

\section{Implications of Elite Theory}

The elite theory recognizes the movement of elite mass conflict. The theory has certain implications for understanding of policy analysis. Michael argued that there was an iron law of oligarchy which operated in organization over time. Organizational elite generate their own interests in goals which are different than those of the masses. Max Weber also showed how rationalization in capital society leads to the formation of bureaucracy which in the absence of strong parliamentary accountability poses a threat to democratic policy making by elected politician.

\section{Criticism and conclusion}

First, decision making, according to the elite theory is a process which works to the advantage of elites in whom power is concentrated. As such, public policy does not reflect the demand of the masses so much, as it does of elites. Therefore changes in public policy occur as a result of redefinition by elites of their own values and choices. Because elites share a consensus in preserving the social system, changes in the public policy are brought about through reform (incremental in nature) when event threaten the system. The stability of the system, therefore, depends on elites sharing in a consensus about fundamental values underlying his system, and only policy alternative that fall within shared consensus will be given serious consideration.

- The value of elite may be welfare oriented for the public. The welfare of the asses may be an important element in elite decision making, but the responsibility for the welfare rest on the shoulders of elites rather than masses.

- $\quad$ Second, elite theory purports that masses are apathetic and ill-informed about the public policy that elites manipulate mass opinion and sentiments on policy questions more than masses manipulate and influence elite values and opinions and that policy flows downwards from the elite to the mass. Therefore, policy questions are seldom decided by the masses through the popular elections or through the presentation of policy options by political parties. For the most part, these elections and 
Vol. 4, No. 1

political parties play their symbolic role. Elitism views the masses as largely apathetic having at best an indirect influence over the policy making process of elites.

\section{Group think theories for policy making}

Group theory of public policy-making is modeled on the 'hydraulic theory of politics. (Zeigler \& Peak, 1972)In this theory policy is viewed as a system of forces and pressures, pushing against one another in the making of public policy. The theory begins with the proposition that interaction among group is the main facts of Politics (Truman, 1951). What may be called public is actually the equilibrium reached in the group struggle in any given moment, and it represents a balance which the contending factions or groups constantly strive to tip in their favor... the legislature referees the group struggle, ratifies the victory of the successful coalition, and records the terms of the surrenders and compromises and conquests in the form of statutes (Latham, 1956). Policy makers in this theory are viewed as responding to group pressures (negotiating and compromising among competing demands of influential groups. Politicians and political parties attempt to form a majority coalition of groups. They select the groups which have diverse interests, to form the majority coalition. The group theory holds that several forces contribute to maintain the equilibrium in whole interest group system. First, a large latent group in the society supports the constitutional system in the country. Second, overlapping group membership helps to maintain the equilibrium by preventing any one group from violating the constitutional system and prevailing values. And third, equilibrium results from group competition. The power of a group is checked by the power of another.

\section{Focus in group think theory}

In this theory, individuals in groups are under the pressure to confirm to group norms and perceptions of information. But the cohesiveness of the group is a major factor in the achievement of task. (Wright, 1970)

\section{Criticisms of Group think theory}

The following are the criticisms of group think theory;

1. The inadequacy of case study method for hypothesis testing

2. The suspiciously perfect correlation between soundness of process and goodness of outcome (the risk of hindsight)

3. Conceptual misspecification of the model

\section{Conclusion}

The evidence provided by research in group theory and group think model is very mixed. There is the general notion that groups can distort decision making. Group theory purports to describe all political activities in terms of group struggle and policy makers are viewed as constantly responding to demands of the influential groups. The cohesion did not have any significant effect on the decision making process. (Flowers, 1977) However, he did find the groups with directive leaders proposed fewer solutions, shared less information and used fewer facts.

\section{References}

Downs, A. (1957). An Economic Theory of Democracy, California: Hoover Institution Press Publication

Dye, T. R., \& Zeigler, H. (2004). The Irony of Democracy. California: Wadsworth Publishing Company.

Flowers, M. L. (1977). A Laboratory test of some implication of Janis's group think hypothesis. Washington DC : Journal of personality and social psychology. 
Higley, John. (2010). Elite Theory and Elites, Handbook of Politics: State and Society in Global Perspective, Springer

Lasswell, H. (1936). Politics:who gets what, when \&how ? Cleveland, Ohio: Meridian Books.

Lasswell, H. (1941). The Garrison State. American Journal of Sociology, 455-468.

Latham, E. (1956). The Group Basis of politics. New York: Free Press.

Michels, R. (1915). Political Parties. London:Werner Klinkhardt

Mills, C. W. (1963). Power Political and People. New York: Oxford University Press.

Mosca, G.(1939) The Ruling Class ,NewYork: McGraw - Hill Book company

Pareto et al. (2014) Manual Of Political Economics, London: Oxford University Press.

Putnam, (1976) the Comparative Study of Political Elites Englewood Cliffs, New Jersey: Prentice-Hall

Schumpeter, J. (1974). Capitalism, Socialism \& Democracy. London: Allen \& Unwin.

Sapru, R.K. (2012). Public Policy: Formulation, Implementation and Evaluation, Noida: Sterling Publishers Private Limited

Schumpeter, J. (1974). American Journal of Sociology, Volume 46, pp. 455-468

Thoenes (1966) The Elite in the Welfare State New York: The Free Press

Truman. (1951). The Governmental Process. New York: Principia Press.

Wright, D. S. (1970). Introducing Psychology: an experimental approach.London: Penguin Books.

Zeigler, \& Peak. (1972). Interest groups in American society. New Jersey: Prentice-Hall. 


\section{Author Guidelines}

\section{About the Journal}

NCC Journal is a multidisciplinary doble blinded peer reviewed journal has been published for the last four years with the aim of exploring the knowledge in all diversified discipline such as management, social sciences, science, banking and finance, statistics, literature, sociology, information and technology, education, globalization, trade, marketing and accounting, law and so on. The journal is a curious inter-linkage of the ideas and ideals of different areas of knowledge.

\section{Journal Publication Process}

- $\quad$ NCC Journal solicits unpublished research articles from academicians and practitioners engaged in various discipline.

- $\quad$ NCC Journal has a strong advisory board, reviewer roster and publication committee.

- Authors should follow the notice published through Nepal Commerce Campus (NCC) website www.ncc.edu.np or in the NCC notice board.

- Authors should send two printed and soft copies of the manuscript, using standard software package MS-word.

- $\quad$ The manuscript should strictly be based on APA format (latest edition).

- The authors' name should not be appeared anywhere on the body of the manuscript to facilitate and influence the review process.

- $\quad$ There should be separate pages for topic and authors name, abstract and body of manuscript followed by the references and appendices.

- The manuscript should be escorted by an abstract (in about 200 words) with not more than five keywords.

- The authors should send a declaration statement to publication committee stating that the paper has neither been published nor will it be submitted elsewhere till the editorial decision from NCC Journal has been communicated.

- The table, charts, graphs, and any other figures should be drawn clearly and legibly. The tables and figures should have a number and title at the top.

- The authors should take consideration and specify wherever necessary about the background, the purpose of study, research gap, conceptual/theoretical framework, research methods, findings, conclusions, discussions and policy implications of the study.

- The manuscript received with all the mentioned guidelines will be forwarded for review process otherwise authors will be notified for further contribution.

\section{Peer Review Policy}

- The preliminary crossed manuscript will be sent to a minimum of two experts from the panel of experts (Double Blinded Peer Reviewed)

- The manuscript will be sent blindly to the reviewer confidentially. Reviewer's bases will be zero.

- The manuscript will be thoroughly reviewed by the reviewer and feedback will be provided to the editorial board. 
- The manuscript will be sent according to the expertise of the reviewer and objective of the manuscript.

- A reviewer is asked to evaluate whether the manuscript is scientifically sound, original, relevant, and clear, whether it correctly referenced, and whether it falls within the scope of the journal.

- If the feedback from the entire reviewer is negative, the manuscript will be rejected or if the positive signal is received from the reviewers, the manuscript will be accepted and notification will be given to the author. If there is a debate in the reviewing process, the manuscript will be sent to more panels of experts and will come up with a decision.

- $\quad$ Authors will be provided the manuscript with feedback from the reviewers which the authors have to amend, update and change if necessary and should send back to the editorial board.

- $\quad$ The complete double-blinded review process will take a minimum of 3 to 4 months from the date of the manuscript received.

\section{Publication Ethics}

The editorial board, publication committee, authors, press, staff and all the concerned of NCC Journal should follow the rules, regulations and norms of Nepal Commerce Campus, Tribhuvan University.

\section{Publication Charges}

NCC Journal is free of cost. The accepted manuscript will be published without taking any charge.

\section{Right of Editorial}

The Editor-in-Chief reserves the full and unregulated rights and the sole discretion to accept or refuse an article for publication.

\section{Certificate of Publication}

The publication certificate and two hard copies of NCC Journal will be provided to the respective authors free of cost. The postal charges, extra copy charges, delivery charges, etc. should bear by the respective authors.

\section{Copyright Notice}

\section{(C) Nepal Commerce Campus, TU}

Authors are required to transfer their copyright to the Nepal Commerce Campus, TU. 